\title{
RNA EXTRACTION FROM SOIL BACTERIUM PSEUDOMONAS PUTIDA AND GREEN ALGA RAPHIDOCELIS SUBCAPITATA AFTER EXPOSURE TO NANOSCALE ZERO VALENT IRON
}

\author{
${ }^{1,2}$ Cheryl S.Y. YEAP, ${ }^{1}$ Nhung H.A. NGUYEN, ${ }^{3}$ Olga Blifernez-KLASSEN, ${ }^{3} J a n$ H. MUSSGNUG, \\ ${ }^{4}$ Tobias BUSCHE, ${ }^{3}$ Olaf KRUSE, ${ }^{1}$ Alena SEVCU \\ ${ }^{1}$ Institute for Nanomaterials Advanced Technologies and Innovation, Technical University of Liberec, \\ Liberec, Czech Republic, EU, alena.sevcu@tul.cz \\ ${ }^{2}$ Faculty of Mechatronics, Informatics and Interdisciplinary Studies, Technical University of Liberec, \\ Liberec, Czech Republic, EU, cheryl.yeap@tul.cz \\ ${ }^{3}$ Algae Biotechnology and Bioenergy, Faculty of Biology, Center for Biotechnology (CeBiTec), Bielefeld \\ University, Bielefeld, Germany, EU, jan.mussgnug@uni-bielefeld.de \\ ${ }^{4}$ Microbial Genomics and Biotechnology, Faculty of Biology, Center for Biotechnology (CeBiTec), Bielefeld \\ University, Bielefeld, Germany, EU, tbusche@cebitec.uni-bielefeld.de
}

https://doi.org/10.37904/nanocon.2020.3764

\begin{abstract}
Soil bacterium Pseudomonas putida and green alga Raphidocelis subcapitata are often used in ecotoxicology studies, including assessment of nanomaterials. Exposure of these microorganisms to reactive nZVI, however, reduce the quality of extracted RNA for further transcriptomic analysis. In this study, we compare RNA extraction using eight extraction protocols. The extraction using the commercial column kits was often unable to elute both the RNA species in a single elution, whereas phenol-chloroform method using RNAzol recovered both small RNA and large RNA from $P$. putida. On the other hand, the column based RNA extraction kit from ISOLATE II RNA Mini gave the best yield approximately of $1 \mu \mathrm{g} / \mu$ l of RNA and RIN 9.0. RNA extraction from $R$. subcapitata was more complicated when we used a similar column based RNA extraction system, it required additional and thorough cell lysis steps that included cell lyophilisation and ribolization prior to phenolchloroform extraction method. Then the yield of an effective RNA concentration ranged from $300 \mathrm{ng} / \mathrm{\mu l}$ to 980 $\mathrm{ng} / \mu \mathrm{l}$, giving the RIN 5.5-7.8. The final protocols solved most of the extraction problems, and allow experiments involving RNA gene expression analysis of microorganisms exposed to reactive $\mathrm{nZVI}$.
\end{abstract}

Keywords: Metal oxides nanoparticles, Iron, Bacteria, Green algae, RNA integrity assessment

\section{INTRODUCTION}

The nanoscale zero-valent iron $(\mathrm{nZVI})$ is well known as a powerful reductant in transforming many hazardous pollutants into safer by-products [1,2]. Ever since the introduction of $n Z V I$ into aquifers, studies of its effect on the aquatic microbial consortia were largely based on phenotypic analysis, cell physiology or mechanisms of contaminant sequestration complianced to the OECD guidelines [3]. In contrast to these studies, little is known about the response of the microorganisms on the transcriptomic level. Isolation of high quality RNA is often not easy, when there are compounds that bind to and/or co-precipitate with RNA or experimental conditions that need special attention to preserve the intergirty of RNA such as the addition of reactive nZVI. Hence, our focus in this study was to optimize the RNA extraction protocol from cells after exposure to $\mathrm{nZVI}$ and iron cations released from oxidized $\mathrm{nZVI}$ ( $\mathrm{nZVI}$ Fe ions) or $\mathrm{nFe}_{3} \mathrm{O}_{4}$ as a control that may interfere with $\mathrm{RNA}$. We used common environmental soil bacterium, Pseudomonas putida NCTC 10936 and freshwater microalga, Raphidocelis subcapitata ATCC 22662. The effectiveness of several RNA extraction methods were compared, including different cell lysis protocols in the case of microalga. 


\section{MATERIALS AND METHODS}

\subsection{Preparation of $\mathbf{n Z V I}$ and its ions}

The supplied NANOFER STAR powder (nZVI) (CAS no: 7439-89-6, size 10-150 nm) and nano $\mathrm{Fe}_{3} \mathrm{O}_{4}\left(\mathrm{nFe}_{3} \mathrm{O}_{4}\right)$ (CAS No: 1317-61-9, size 50-100 nm) were obtained from NANOIRON s.r.o, Czech Republic, and Sigma Aldrich, Merck, Germany, respectively. Activation of $20 \%$ nZVI suspension was done according to producer guidelines for $48 \mathrm{~h}$ [4]. Simultaneously, the aqueous phase of $\mathrm{nZVI}$ slurry containing iron cations $\left(44.5 \mu \mathrm{g} \mathrm{L}^{-1}\right)$ released from oxidized $n Z V I$ was prepared by high speed centrifugation twice at 14, $000 \times g$ for 20 min per cycle separating the supernatant from $\mathrm{nZVI}$ and served as one of the exposure condition (nZVI Fe ions).

\subsection{Culture condition and experimental setup}

\subsubsection{P. putida}

Pseudomonas putida NCTC 10936, was obtained from CCM Czech Collection of Microorganisms, Brno, Czech Republic. The cells were grown in tryptone soy medium at $30^{\circ} \mathrm{C}$ and when reaching its mid-log phase, $10 \mathrm{ml}$ of $P$. putida $\left(3.3 \times 10^{8} \mathrm{cells} / \mathrm{ml}\right)$ was harvested and transferred immediately to the nanoparticle exposure medium. Three different experimental conditions were prepared: i) unexposed $P$. putida (control), ii) $P$. putida with $44.5 \mu \mathrm{g} \mathrm{L}{ }^{-1} \mathrm{nZVI} F e$ ions and, iii) $P$. putida with $100 \mathrm{mg} \mathrm{L}^{-1} \mathrm{nZVI}$. Whole experiment was performed at room temperature in $250 \mathrm{~mL}$ Erlenmeyer flasks containing $50 \mathrm{~mL}$ of exposure medium consisting of carbonate buffer (1,5 mg L-1 $\mathrm{Na}_{2} \mathrm{CO}_{3}$ and 167,16 mg L-1 $\mathrm{NaHCO}_{3}, \mathrm{pH} 8.0$ ), cells and treatments, shaken at $120 \mathrm{rpm}$ and immediately sampled $(50 \mathrm{~mL})$ for RNA extraction. After optimizing the suitable RNA isolation method for $\mathrm{nZVI}$ spiked samples, a natural reservoir water (NRW) was collected in a spade from a local reservoir on 18 November 2018, filtered through $0.2 \mu \mathrm{m}$ Whatman membrane filters, and served as the media in next experiment that followed the same conditions as described above.

\subsubsection{R. subcapitata}

Raphidocelis subcapitata ATCC 22662, was obtained from Culture Collection of Autotrophic Organisms (CCALA, Czech Republic). The culture was cultivated under a $130 \mu \mathrm{mol}$ photons $\cdot \mathrm{m}^{-2} \mathrm{~s}^{-1}$ of constant white light illumination and gently bubbled by $1 \% \mathrm{CO}_{2}$ mixed with air at room temperature $\left(24^{\circ} \mathrm{C}\right)$. The cultivations were conducted in a $500 \mathrm{~mL}$ flask containing Sueoka's high salt medium (HSM) [5]. Three different experimental conditions were set up, namely the: i) unexposed $R$. subcapitata (control), ii) $R$. subcapitata with $100 \mathrm{mg} \mathrm{L}^{-1}$ of $\mathrm{nFe}_{3} \mathrm{O}_{4}$ and iii) $R$. subcapitata with $100 \mathrm{mg} \mathrm{L}^{-1}$ of $\mathrm{nZVI}$. A $35 \mathrm{~mL}$ culture was sampled immediately after nanoparticle mixture with cells in HSM for RNA extraction.

\subsection{RNA isolation}

\subsubsection{P. putida}

Eight RNA extraction protocols from several manufacturers including TRI reagent, RNAzol (Molecular Research Center, United Kingdom), TRIzol (Invitrogen, USA), DirectZol, Quick DNA/RNA microprep (Zymo Research, USA), NucleoSpin RNA Plus, NucleoSpin miRNA (Macherey Nagel, Germany) and ISOLATE II RNA Mini (Bioline, Canada) were used for the comparison. Based on our preliminary experiments, the magnetic $n Z V I$ particles had to be removed by a strong nickel-plated block magnet $(70 \mathrm{~mm} \times 70 \mathrm{~mm} \times 25 \mathrm{~mm}$ ) with a magnetic force approximately at $180 \mathrm{~kg}$ to minimize interference with RNA. The cell lysis and extractions were done according to the manufacturer's protocols. Complete elimination of contaminating residual DNA was further done with TURBO DNA-free ${ }^{\mathrm{TM}}$ kit (Invitrogen, USA). The integrity of the total RNA was determined by 2200 TapeStation system (Agilent Technologies, Germany) and the concentration using Qubit ${ }^{\mathrm{TM}}$ (Life Technologies, USA). All electropherograms of ribosomal RNA (rRNA) peaks were computed and analysed by TapeStation software version A.02.02 SR1 (Agilent Technologies, Germany). 


\subsubsection{R. subcapitata}

RNA isolation of microalgae $R$. subcapitata involved two major steps: the cell lysis and then the RNA extraction procedure. Several cell lysis methods were first compared using cell ribolization on a ribolyzer, liquid nitrogen grinding, and overnight cell lyophilisation at $-30^{\circ} \mathrm{C}$ to effectively lyse the cell walls while releasing the cellular components. To compare different cell lysis method used, the disintegration of the microalgae cell membranes were then imaged under optical microscopy (Motic BA310, Motic, China). The efficiencies of three on-column RNA extraction protocols including ISOLATE II RNA Plant mini (Bioline, Canada), Quick-RNA ${ }^{\text {TM }}$ Miniprep kit (Zymo Research, U.S.A), RNeasy Plant Mini kit (Qiagen, Germany), and phenol-chloroform extraction [6] were compared to extract the RNA following the manufacturer's instructions. Untreated cell pellets and cells exposed to $\mathrm{nFe}_{3} \mathrm{O}_{4}$ and $\mathrm{nZVI}$ were obtained through centrifugation at $10000 \times \mathrm{g}$ for $3 \mathrm{~min}$ at $4{ }^{\circ} \mathrm{C}$ and were subjected to different cell lysing methods mentioned above. The nanoparticles were not removed by the magnet for the studies of microalgae. The cell pellets including the retained nanoparticles were then immediately transferred into ZR BashingBeads ${ }^{\mathrm{TM}}$ Lysis Tubes (Zymo Research, USA) and added the RNA lysis buffer or aqua phenol was added. The tubes were put to liquid nitrogen and cell beating was performed in a ribolyzer (Precellys, France) at $6500 \mathrm{rpm}$ for a total of two beating cycles with $45 \mathrm{~s}$ per cycle and $15 \mathrm{~s}$ break in between cycles. The subsequent RNA washing steps and recovery of both small and large RNA fractions were followed as instructed in the RNA purification protocol (Zymo Research, U.S.A) or isopropanol/ethanol washing using the phenol-chloroform extraction. Complete DNA removal was performed using on-column treatment and clean RNA extracts were eluted in diethylpyrocarbonate (DEPC) treated water. The integrity and concentration of the RNA extracts were determined respectively with an Agilent 2100 Bioanalyzer system (Agilent Technologies, Germany) and Nanodrop (Thermo Scientific, USA). All electropherograms of rRNA peaks were computed and analysed by 2100 Expert software (Agilent Technologies, Germany).

\section{RESULTS AND DISCUSSION}

\subsection{Evaluation of efficient RNA extraction method from nanoparticle spiked medium}

We tested and evaluated different RNA extraction protocols on the bacterium $P$. putida and green alga $R$. subcapitata in the presence of reactive nZVI. Based on our preliminary P. putida-nanopaticle study, the nZVI particles were removed using a strong magnet from the culture before the RNA extraction. This step prevented clogging of the columns later during the RNA washing step and, importantly enabled to yield a higher quality of RNA. A strong magnet of magnetizing force of $180 \mathrm{~kg}$ was capable to remove most of the nZVI particles. On the contrary, the nanoparticles were not removed in the case of $R$. subcapitata exposure and the RNA extraction was performed with the nanoparticles present in the culture. The two different sampling methods, although yielded desirable RNA quality, need further care because with $n Z V I$, also part of the cells could be retained or, on the other hand, nZVI could react with lysis buffer when left in the culture.

\subsubsection{RNA extraction from $P$. putida}

Eight different extraction protocols have been compared including on-column and phenol-chloroform extractions. RNA extraction by the phenol-chloroform method was able to recover both small and large fractions of RNA (Figures 1A-D) while RNA extraction using most of the commercial column kits were often unable to elute both the RNA types in a single elution (Figures 1E-H). Phenol extraction using RNAzol and on-column extraction using Bioline ISOLATE II RNA mini kit exhibited the highest extraction efficiency with the RNA integrity number (RINe) and RNA concentrations shown in Figure 1. Each of these extraction methods (RNAzol and Bioline RNA mini) in general yield a similar RINe value in comparison to the untreated control and $n Z V I$ spiked samples which can be seen in their RINe from RNAzol extraction (RIN $\mathrm{N}_{\text {control: }}$ 7.7; $R I \mathrm{~N}_{\text {nzVI: }}$ 7.9), (Figure 1C) and RINe from Bioline ISOLATE II RNA mini kit (RIN $\mathrm{C}_{\text {control: }}$ 9.0; RIN $\mathrm{N}_{n \mathrm{VV}}$ : 8.9), Figure 1G. In general, Bioline ISOLATE II RNA mini kit has been chosen for our following analysis of the $P$. putida-nZVI spiked samples, as the extraction outcome yielded the highest RINe. 


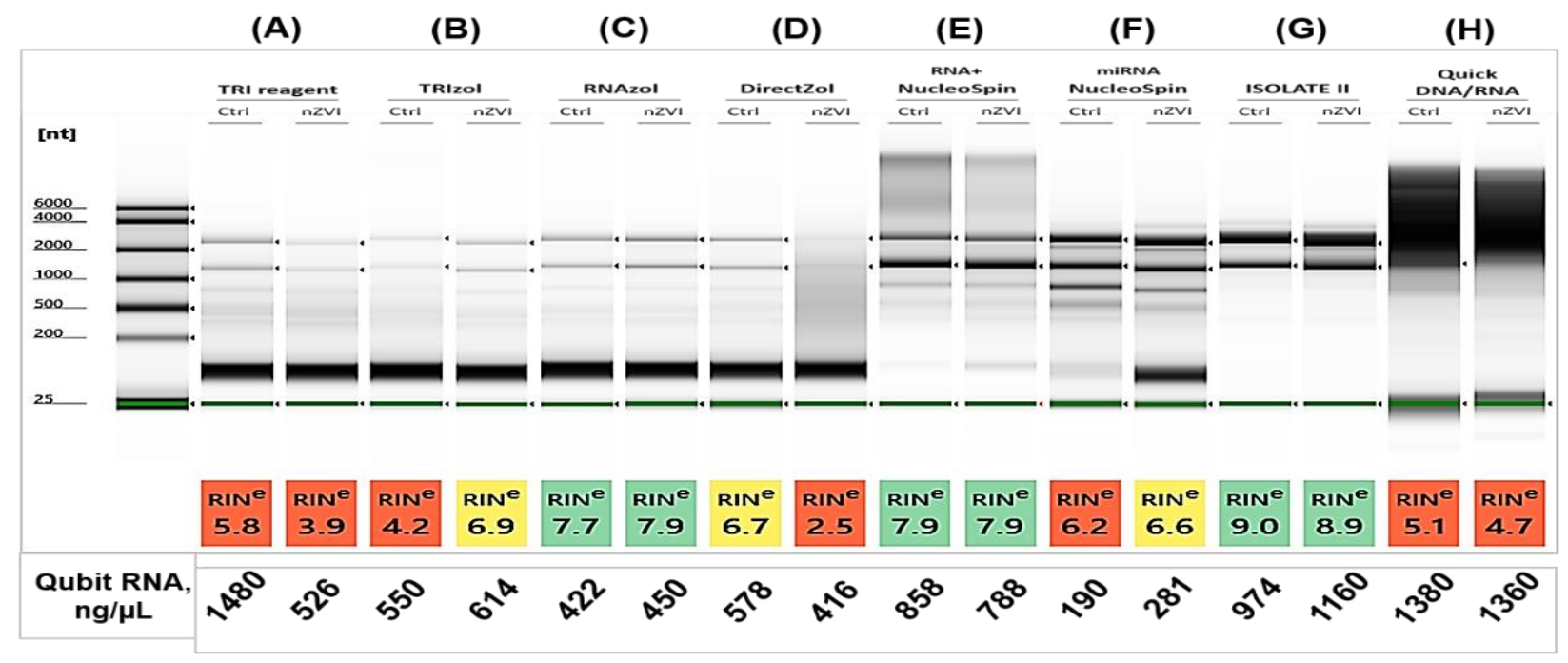

Figure 1 Comparison of RNA extraction methods performed on $P$. putida-nZVI samples in carbonate buffer $\left(\mathrm{pH}\right.$ 8.0) on a TapeStation system based on RNA integrity number $\left(\mathrm{RIN}^{\mathrm{e}}\right)$ and RNA concentrations are shown in the bottom line. Ctrl: condition without nZVI, nZVI: with nZVI. Different RNA extraction methods used were: (A) TRI reagent, (B) TRIzol, (C) RNAzol, (D) DirectZol, (E) RNA Plus NucleoSpin, (F) miRNA NucleoSPin, (G) ISOLATE II, (H) Quick DNA/RNA

The RNA extraction efficiency by Bioline ISOLATE II RNA mini kit isolated from control, nZVI Fe ions and nZVI spiked samples is shown in Figure 2A. The representative electropherogram peaks of the control, nZVI Fe ions and $\mathrm{nZVI}$ clearly showed the intact $16 \mathrm{~S}$ and $23 \mathrm{~S}$ peaks (Figures 2C-E). Based on our experience, optimizing a suitable RNA extraction method for such difficult samples could be a daunting process at the beginning, especially when the information on the sample/organisms are still scarce. The consistency of the RIN $N^{e}$ obtained is important when selecting a suitable extraction assay fitting to the biological properties of the samples, especially when working with many treatment conditions in parallel and a huge number of samples.

(A)

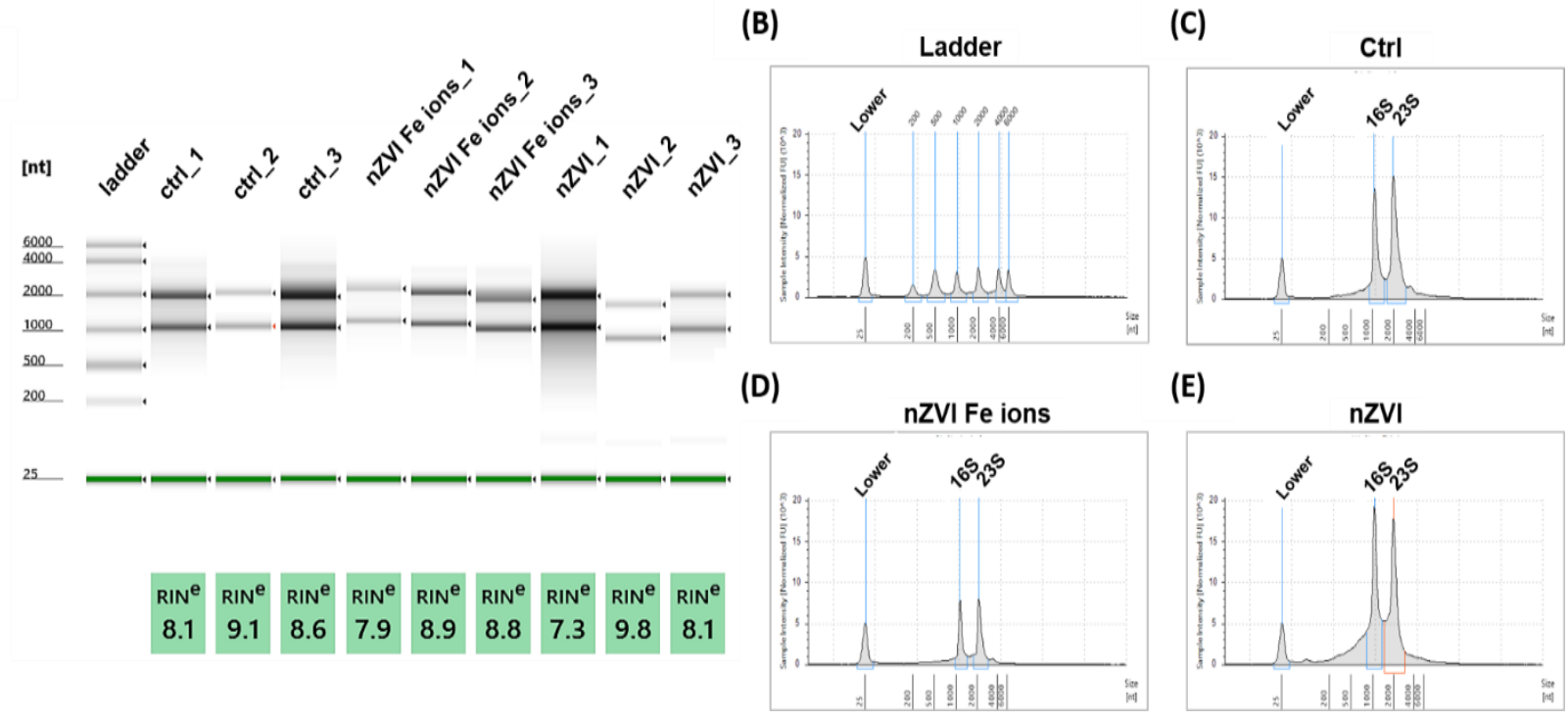

Figure 2 RNA integrity numbers of all isolated RNA from $P$. putida samples exposed to $\mathrm{nZVI}$ Fe ions and $n Z V I$ compared on a TapeStation system (A), and electropherograms of rRNA peaks of RNA ladder (B), control (C), nZVI Fe ions (D), nZVI (E) using Bioline ISOLATE II RNA mini kit 


\subsubsection{RNA extraction of $R$. subcapitata}

The cell lysis efficiency by liquid nitrogen grinding, cell ribolization, and cell lyophilization was evaluated using R. subcapitata when in contact with $100 \mathrm{mg} \mathrm{L}^{-1} \mathrm{nFe}_{3} \mathrm{O}_{4}$ or $\mathrm{nZVI}$. Prior to that, the integrity of the cells were screened using a light microscope (Figure 3 ) by comparing the efficiencies of different cell lysis method used. The cells after the liquid nitrogen grinding looked very similar to those in control samples, where only a small amount of cells were lysed (Figures $\mathbf{3 A}, \mathbf{B}$ ). A previous genome study of $R$. subcapitata [7] described successful isolation of RNA from a $100 \mathrm{~mL}$ culture using the same liquid nitrogen grinding method, however, it should be noted that the isolation of RNA from a $100 \mathrm{~mL}$ culture, by theory should yield higher RNA compared to our culture volume of $35 \mathrm{~mL}$. $R$. subcapitata belongs to the family Selenastraceae, is a robust microalgae containing very rigid polysaccharide-based cell wall recalcitrance to breakage $[7,8]$. These polysaccharides, upon cell disruption, co-precipitates the RNA [9] which then complicated the RNA extraction procedure and resulted low yield/quality of RNA. In our study, the RNA extraction protocol has been tailored to $R$. subcapitata using cell lysis procedure combining the overnight lyophilization of cells followed by ribolization of the cells resuspended in RNA lysis buffer resulted in the highest lysis efficiency (Figure 3C).

(A) Control

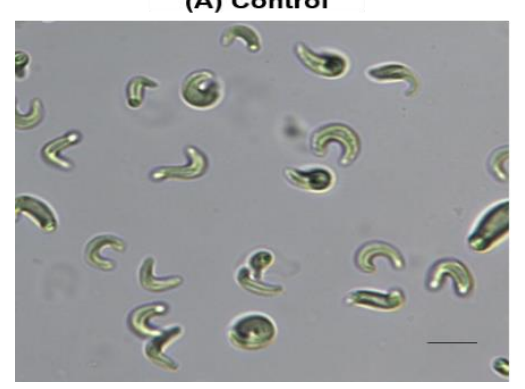

(B) Liquid nitrogen grinding

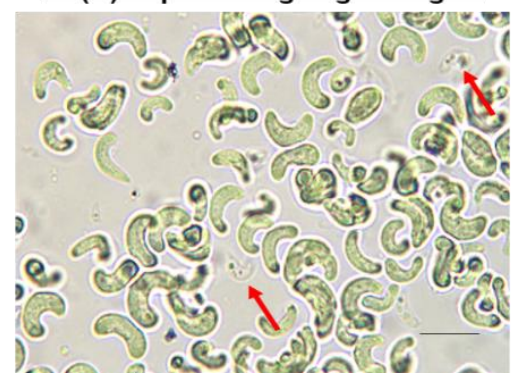

(C) Lyophilization + ribolization

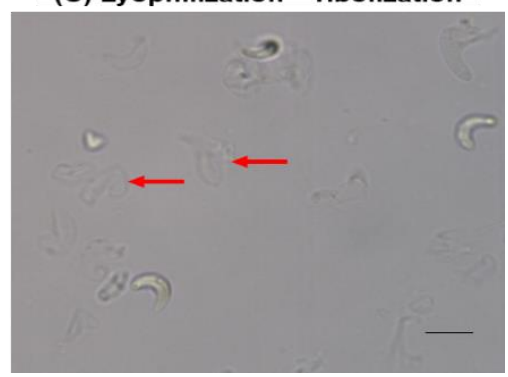

Figure 3 Light microscopic images of $R$. subcapitata cell lysis before RNA extraction: A - control cells before lysis, $B$ - cells after liquid nitrogen grinding, $C$ - overnight lyophilisation of wet biomass prior to ribolization.

Red arrows indicate the lysed empty cells. Scale bar $=15 \mu \mathrm{m}$

The efficiency of different RNA extraction methods were then compared. Among the tested methods, phenolchloroform extraction yielded the highest RIN working with the $R$. subcapitata-nanoparticles spiked samples and is shown in Figure 4. The representative electropherogram peaks of the experimental condition in respective to control, $\mathrm{nFe}_{3} \mathrm{O}_{4}$ and $\mathrm{nZVI}$ show the $18 \mathrm{~S}$ and $28 \mathrm{~S}$ peaks (Figures 4B-D).

(A)

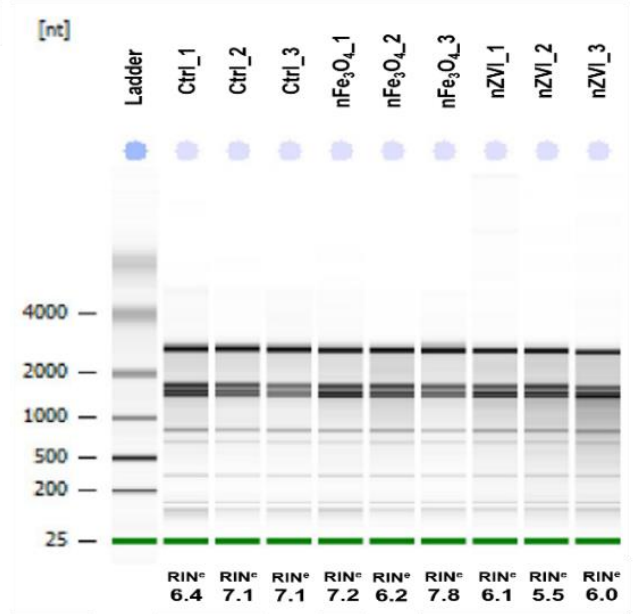

(B)

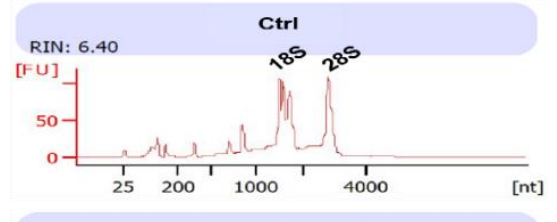

(C)

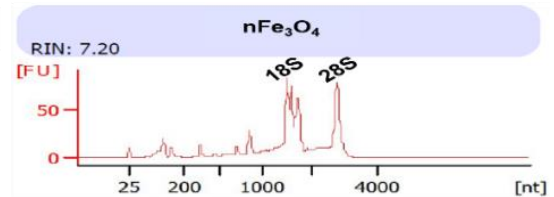

(D)

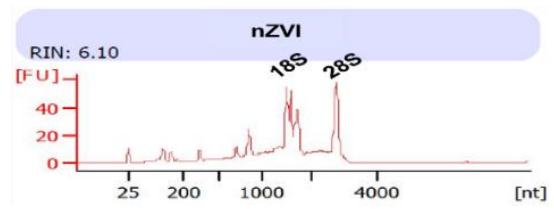

Figure 4 RNA integrity numbers of all isolated $R$. subcapitata samples compared on a bioanalyzer system $(A)$, and electropherogram of rRNA peaks of untreated control $(B), n F e_{3} \mathrm{O}_{4}(C), n Z V I(D)$ using phenolchloroform extraction method 


\section{CONCLUSION}

Based on our data, extraction of the RNA from $P$. putida-nZVI samples was straightforward using the columnbased extraction kit (Bioline ISOLATE II RNA Mini) while isolation of the RNA from freshwater microalgae $R$. subcapitata in $\mathrm{nZVI}$ or $\mathrm{nFe}_{3} \mathrm{O}_{4}$ spiked samples required an initial step including thorough cell lysis by combining overnight lyophilization of wet biomass, followed by ribolization of the dried biomass suspended in phenol and finally RNA isolation through phenol-based extraction. Presence of $\mathrm{nZVI}$ in the sample during cell lysis and RNA extraction did not considerably harmed the RNA isolated from $R$. subcapitata. In general, the columnbased RNA extraction methods are recommended, except when isolation is compromised by polysaccharides or compounds which can bind to and/or co-precipitate with RNA. In such cases, phenol-based extraction methods may offer higher quality RNA obtained.

\section{ACKNOWLEDGEMENTS}

This project was financially supported by the Technical University of Liberec through project No. PURE-2019800 (Environmental fate, behaviour and biological effects of engineered nanomaterials) and partly by German Academic Exchange Service short term grants, 2019 (57440917). The authors acknowledge the assistance provided by the Research Infrastructures NanoEnviCz (Project No. LM2018124) supported by the MŠMT of the Czech Republic

\section{REFERENCES}

[1] TRATNYEK, P. G. and JOHNSON, R. L. Nanotechnologies for environmental cleanup. Nano Today. [online]. 2006, vol. 1, no. 2, pp. 44-48. Available from: https://doi.org/10.1016/S1748-0132(06)70048-2.

[2] SCHMID, D., MICIĆ, V., LAUMANN, S., HOFMANN, T. Measuring the reactivity of commercially available zerovalent iron nanoparticles used for environmental remediation with iopromide. J. Contam. Hydrol. [online]. 2014, vol. 181, pp. 36-45. Available from: https://doi.org/10.1016/i.jconhyd.2015.01.006.

[3] Guidance document on aquatic and sediment toxicological testing of nanomaterials. [Online]. Paris, Jul. 2020. [Accessed: Sep. 15, 2020]. Available from: www.oecd.org/chemicalsafety/.

[4] NANOFER STAR | NANOIRON. [accessed Sep. 14, 2020]. Avalaible from: https://nanoiron.cz/getattachment/7aa3e8c5-5701-4a47-b05c-b91f87279aae/NANOFER-STAR-processingactivation-manual.aspx.

[5] SUEOKA, N. Mitotic replication of deoxyribonucleic acid in chlamydomonas reinhardi. Proc. Natl. Acad. Sci. [online]., 1960, vol. 46, no. 1, pp. 83-91. Available from: https://doi.org/10.1073/pnas.46.1.83.

[6] CHOMCZYNSKI, P. and SACCHI, N. The single-step method of RNA isolation by acid guanidinium thiocyanatephenol-chloroform extraction: twenty-something years on. Nat. Protoc. [online]. 2006, vol. 1, no. 2, pp. 581-585. Available from: https://doi.org/10.1038/nprot.2006.83.

[7] SUZUKI, S., YAMAGUCHI, H., NAKAJIMA, N., and KAWACHI, M. Raphidocelis subcapitata (=Pseudokirchneriella subcapitata) provides an insight into genome evolution and environmental adaptations in the Sphaeropleales. Sci. Rep. [online]. 2018, vol. 8, no. 1, pp. 1-13. Available from: https://doi.org/10.1038/s41598-018-26331-6.

[8] BURCZYK, J. and DWORZANSKI, J. Comparison of sporopollenin-like algal resistant polymer from cell wall of Botryococcus, scenedesmus and lycopodium clavatum by GC-pyrolysis. Phytochemistry. [online]. 1988, vol. 27, no. 7, pp. 2151-2153. Available from: https://doi.org/10.1016/0031-9422(88)80115-8.

[9] DOS REIS FALCÃO, V., PEDROSO TONON, A., CABRAL OLIVEIRA, M. and COLEPICOLO, P. RNA isolation method for polysaccharide rich algae: Agar producing Gracilaria tenuistipitata (Rhodophyta). J. Appl. Phycol. [online]. 2008, vol. 20, no. 1, pp. 9-12. Available from: https://doi.org/10.1007/s10811-007-9174-7. 